\title{
The Ecolinguistics of Malay Langkat Mantra
}

\author{
Muhammad Natsir ${ }^{1}$, Bahagia Saragih ${ }^{2}$, Rafika Dewi Nst. ${ }^{3}$, \& Puan Suri Mira A. ${ }^{4}$ \\ 1,2,3\&4 Universitas Negeri Medan, Indonesia
}

\begin{tabular}{l}
\hline \hline ARTICLE INFO \\
\hline \hline Article history: \\
Received Nov 28, 2019 \\
Revised Jan 02, 2020 \\
Accepted March 02, 2020 \\
\hline Keywords: \\
Ecolinguistics, \\
Mantra, \\
Malay Society, \\
Medicine Man, \\
Flora \& Fauna \\
\hline
\end{tabular}

\begin{abstract}
This paper deals with the description of ecolinguistics on Malay Langkat mantra. The main objective of this paper is to explore especially the Malay Langkat mantra (especially those related to traditional medications) on the basis of the ecolinguistic study. Malay Langkat mantra was very popular amongst the Malay Langkat society in the past. The mantra was used by traditional medicine man called pawang/bomoh/dukun. He commonly has supernatural ability in medicating the local society in almost all kinds of diseases. The medication man has his own specific mantra for specific diseases and it is believed by the society that the diseases will relieve soon after the medication man read the mantra. The mantra themselves consist of short sentences in the forms of traditional poetry. They sometimes used words or phrases taken from the nature (flora and fauna)
\end{abstract}

\section{Clonflict of Interest:}

None

Funding:

None

Corresponding Author: Muhammad Natsir, Faculty of Languages and Arts, Universitas Negeri Medan and Jln. Willem Iskandar Psr. V. Kecamatan Percut Sei Tuan, Kabupaten Deli Serdang, Sumatera Utara 20221, Indonesia Tel. +62812-6099-0104. E-mail: mnatsir0@gmail.com.

\begin{tabular}{ll}
\hline CC) & (C) Muhammad Natsir, Bahagia Saragih, Rafika Dewi Nst., Puan Suri Mira A. \\
This is an open access article under the CC BY-SA 4.0 international license.
\end{tabular}

1. Introduction

Malay Langkat medication can be defined as a cultural system based on the beliefs, knowledge and practices related to the concept of well-being of the life in the community as a whole, though basically it concerns sickness and indisposition. Like any other forms of medicine, Malay Langkat medical practice covers three main aspects, i.e. (1) curing, (2) healthcare. and (3) prevention diseases. Malay Langkat medical practitioners or medicine men are known as pawang/dukun, bomoh, tabib.

Historicaaly, Islam arrived in the Malay world equipped with the medical aspects which emphasize the treatment of rukyah (incantation), and this is parallel to the usage of spell (mantera) which became the practice of the Malay community before the arrival of Islam. The mantera continued to experience the process of adapting to the Islamic influences in the Malay land as late as 15th century. The contents of mantera were replaced by prayer (doa) using the verses from the al-Quran and the words of the prophet Muhammad SAW. There are mantera which are known as prayer (doa) and have Quranic verses which at least begin with 'Bismillah' (in the name of Allah, God Almighty). During incantation, the pronunciation such as 'salam', 'syahadah', 'Bismillah', i.e., name and attribute of Allah SWT, God Almighty, name of rasul and prophet, the name of Islamic warrior and many other names which show the Islamic influence. Most of the contents of mantera have been changed or adapted into rukyah (incantation) which contains holy verses from al-Quran or hadith of the Prophet SAW to adhere to the laws of Islam which are related to Allah 
SWT, God Almighty. Among other, the word 'incantation' is used to represent the word 'rukyah' in reference to the usage of the words which have the same roles to treat and prevent sickness, especially in relation to jinn and devil. The word mantera in the Arab language is referred to as 'rukyah' which means 'protection'. In other words, asking the protection against evil. It has also been known as 'al-muawwizat' which also means 'protection'. The usage of rukyah is frequently used than the word muawwizat. The Islamic ways of treatment through rukyah (incantation), among other, are surah al-Fatihah, al-Kursi verse, muawwidhat verses (surah an-Nas and surah al-Falaq), etc. As such, spiritual healing by rukyah (incantation) involves the spiritual aspects that require the practitioner to return to fitrah tawhidiyyah which is to humble oneself with confidence that everything that happens is Allah SWT's will. This treatment is an effort to cleanse the soul with the belief that each illness created by Allah SWT will have a cure. The illness is a form of test from Allah God Almighty, to his followers, who are always patient.

The treatment through rukyah (incantation) is done as a spiritual healing method by many Malay Langkat traditional healers known as 'pawang/dukun, bomoh, tabib. Even though there are some opinions which suggest that the practice by the Malay Langkat traditional medicine are different from the Islamic medicine, but historically, the Malay Langkat traditional medicine was assimilated with the Islamic medicine after the arrival of Islam to this region. Before the arrival of Islam, the institution of pawang/dukun, bomoh, tabib was the social institution in the Malay community and they still maintain their role in giving advice to the Malay Langkat community for their well-being, especially in the aspect of health even after the arrival of Islam.

This shows that a bomoh pawang/dukun, tabib is still carrying their role even after the arrival of Islam. In addition, an imam is still being consulted whenever there is a problem, particularly when it is related to an illness in the belief that the prayers from Imam are easily accepted by Allah SWT, God Almighty with that being said, the role of imam is directly connected with the role of pawang/dukun, bomoh, tabib, and hence, he is also called a pawang/dukun, bomoh, tabib in treating illnesses even though the four words have its own meaning and use.

\section{The Study of Ecolinguistics}

The concept of ecology itself, which has done so much to further our understanding of the existence, development and extinction of biological species, can provide interesting innovations in the linguistic field, and in the sociocultural field as a whole. The decision not to study linguistic objects and events as if they existed in a vacuum in isolation from other facts and phenomena but to see them as entities interrelated multidimensionally with their context is a huge step forward. The creation, then, of a 'linguistic' ecology which analogously transfers "the study of relationships between organisms and their environment" (Brown, 1995:18) to the level of the language behavior of humans and promotes the study of the relations between language varieties and their geodemosociopolitical contexts may be illuminating for linguistics, which is still excessively centred on the code.

The ecological approach stresses the 'whole' rather than the parts, and makes us fully aware of the interrelation of phenomena of reality and of the key nature of these interdependencies inside the ecosystem in which the organisms themselves live, since in the systemic view - the basis of the ecological perspective objects are principally networks of relationships embedded in larger networks (Capra, 1997:37). From the viewpoint of sociolinguistics and from that of general linguistics as well, the ecological metaphor is illuminating. On the one hand it allows us a better understanding of the vicissitudes of human systems of communication, and on the other it allows us to integrate these systems holistically in the world of social interaction, which they contribute to building (see Bastardas, 1996 and 1999).

In addition, the dynamic conceptualization of the ecosystems restores the temporal dimension to linguistic phenomena, a dimension often neglected by the mainstream approaches of the twentieth century. "Ecosystems can be seen more powerfully as sequences of events rather than as things in a place. (...) Ecosystems are process-oriented and more easily seen as temporally rather than spatially ordered" (Allen \& H., 100). Rather than 'objects', then, there are events and processes, a fact that questions the still prevailing tendency in social and cultural sciences to treat statically and mechanically what exists as a meaning/action/emotion in human beings in society. The dynamic and ecosystemic perspective thus urges us to see reality as a process, not only as a 'structure'. From an ecological perspective, evolution is always coevolution, since all organisms evolve interdependently with the others in their environment. Similarly, the evolution of human languages and verbal behaviors coevolve in conjunction with demographic, socioeconomic, political, and technological events in their milieus.

Languages may intervene in the configuration of the events that affect other phenomena, and these events may affect the organization of the languages. For example, the political configuration of a State may be affected by the distribution of the linguistic groups that compose it; at the same time the political decisions of this State may have an enormous effect on the existence of these linguistic groups. Other concepts derived 
from the ecological perspective also offer conceptual clarifications that are useful for our understanding of sociolinguistic phenomena. For example, the differentiation between 'population' and 'community' is interesting. 'Population' denotes a particular species, but 'community' describes the set of species that coexist in a particular habitat. More specifically, "the difference between a community and a mere collection of organisms is the accommodation that the different species make for each other. The community is not the presence of a particular set of organisms; it is the difference in the organisms because the other community members can be expected to be present. (...) A community at an instant is the embodiment of prior processes of accommodation, for example character displacement where a species has been selected to avoid direct confrontation with another species" (Allen \& H., 1992 127). Transferred to the linguistic field, 'population' could be used to designate a specific first language group (L1), while 'community' would refer to those societies formed by distinct first language groups, with some degree of mutual influence and adaptation.

Fishman (1991), one of the principal theoreticians on language revival, has strongly emphasized the rationality of this wish and we can now witness a reframing of the question, 'How can we achieve greater efficiencies through the reduction and streamlining of diversity?' to a new question, 'How can linguistic diversity be employed in solving social, environmental and technological problems?' This reframing goes hand in hand with the emergence of a new paradigm, the ecological paradigm in many areas of enquiry, including linguistics (Fill \& Mühlhäusler (eds) 2001/Mühlhäusler 2002).

The ecological paradigm has a number of characteristics, including the following: (1) considerations not just of system internal factors but wider environmental ones; (2) awareness of the dangers of monoculturalism and loss of diversity; (3) awareness of the limitations of both natural and human resources; (4) long-term vision; and (5) awareness of those factors that sustain the health of ecologies. A fundamental principle of management is that one can only manage what one knows. Two related principles are one can only manage what one can talk about and one can only manage what one cares for. This paper aims at exploring existing knowledge on the issue of speech communities and to draw attention to the important issue of talking about the phenomenon - the use of flora and fauna words for the medium of communication.

It is argued that existing knowledge is patchy and that un-reflected use of words such as 'language,' 'tribe' or 'community' make management very difficult and whether political and economic leaders care about languages remains to be seen. An appreciation of linguistic diversity alone, it is argued, is not enough. It presupposes an understanding of the nature of this diversity. The complexity of the issues, the limitations of time and space and the urgency of action make it necessary to resort to shortcuts, simplification and abstractions and, above all, focusing on a smaller selection of parameters that are desirable in a parameterrich ecological approach.

This paper shall further be guided by Haugen (1972) who in his seminal paper 'The Ecology of Language' has suggested a list of questions to be asked. For any given 'language', then, we should want to have answers to the following ecological questions: (1) What is its classification in relation to other languages? This answer would be given by historical and descriptive linguists; (2) Who are its users? This is a question of linguistic demography, locating its users with respect to locale, class, religion or any other relevant grouping; (3) what are its domains of use? This is a question of sociolinguistics, discovering whether its use is unrestricted or limited in specific ways; (4) what concurrent languages are employed by its users? We may call this a problem of dialinguistics, to identify the degree of bilingualism present and the degree of overlap among the languages; (5) what internal varieties does the language show? This is the task of a dialectology that will recognize not only regional, but also social and contactual dialects; (6) what is the nature of its written traditions? This is the province of philology, the study of written texts and their relationship to speech; (7) To what degree has its written form been standardized, i.e., unified and codified? This is the province of prescriptive linguistics, the traditional grammarians and lexicographers.

The ecological view would appear to be the most complex, but at the same time the most realistic as it caters for the fact that languages combine independence from the world with dependency on the world as well as their ability to shape the world through a range of ecological interdependencies. The problem with finding a satisfactory definition of language is encountered again when defining the notion of community.

Language has long been studied as a powerful tool in the cultural reflection and constitution of human perception. Whorf (1939/1997:459) famously argued that while language patterns and cultural norms grow up together, constantly influencing each other, it is language that instills limits. "In this partnership the nature of the language is the factor that limits free plasticity and rigidifies channels of development in the more autocratic way". A Whorfian approach, in its deterministic form, assumes distinctions in both understanding and experience on the basis of linguistic distinctions. Evidence, however, to establish such clear-cut distinctions in experience and understanding has been notoriously difficult to come by.

Whorfian views contemporarily have been revisited in a "weakened" form that recognizes his ideas as both suggestive and profound, but as pre-figuring a set of more nuanced understandings of how communication 
does or does not shape thought and action. One example is the work of Philipsen (2002:59), who argues that every communal conversation bears traces of culturally distinctive means and meanings of communicative conduct. In addition, Philipsen argues communication itself is "a heuristic and performative resource for performing the cultural function in the lives of individuals and communities".

Another example is offered by Montgomery (1994:175), who argues communication is a cultural resource that serves to shape and color perceptions by setting limits on the choices of representations and meanings available for the situation at hand. These tools of representation and understanding have been shaped by the society, or by those parts of it, to which a speaker belongs, making more evident certain choices for thinking and acting and making more obscure other choices. A weakened Whorfian position, therefore, claims that "language plays an active and crucial - if qualified - role in shaping (though not completely determining) the processes of representation, by 'pointing us toward different types of observation' and 'predisposing certain choices of interpretation'.

As people must inevitably draw upon linguistic formations in comprehending the world, the argument is put forth that language is "interested," meaning there is no "absolutely neutral and disinterested way of apprehending and representing the world.

Language always helps to select, arrange, organize, and evaluate experience, even when we are least conscious of it doing so" (Montgomery, 1994:176). In fact, Montgomery argues language patterns not only represent ideologies but are in themselves ideologies, as certain dominant styles of communication prefer certain ways of seeing and thinking about an event. "The more widely and pervasively a structure circulates, especially in privileged communicative contexts ... the more difficult it becomes to select differently - and hence to see and think differently about the depicted events" (Montgomery, 1994:193).

As such, communication does not take place within a vacuum. Instead "each structurally generated word gets its meaning by virtue of its systematic relatedness to other words within its respective structure" (Huspek, 1993:15). To be understood, one must select from words that in this way are systematically related to existing structures. Most communication, or discursive production, is thus a reproduction of existing and "interested" structures.

Swidler $(2001: 6,12)$ adds to this conversation by arguing that even within a common culture, communicative resources can be used in very different ways. "Thus, effective cultural explanation depends on understanding how culture is put to use" As culture is now widely defined as "the publicly available symbolic forms through which people experience and express meaning", there is also generally wide agreement that culture is not a unified system. Instead, Swidler speaks of culture as working like a repertoire from which people draw cultural meanings and cultivate skills and capacities that they integrate into larger, more stable "strategies of action." People are constantly actively selecting among the diverse perspectives available. "Indeed, most of our active cultural involvement in everyday life is not joyful participation in shared ritual, but the demanding work of dismissing, criticizing, or filtering the culture with which we come in contact. Thus much of our 'traffic with symbols' (to use Clifford Geertz's phrase) is of a rejecting rather than an accepting sort" (pp. 1516). Swidler argues that the ability to describe a perspective as cultural, or to see culture at all, comes only from skepticism about it. In contrast, cultural perspectives that people accept fully seem to them to be common sense. Swidler states that the pervasiveness of indifference and skepticism in cultural life means one cannot study culture by simply studying the publicly available repertoire of expressive symbols, but instead one must have a way of observing what people believe and what they know and disbelieve. "The analytic problem then is to describe the varied ways people use diverse cultural materials, appropriating some and using them to build a life, holding others in reserve, and keeping still others permanently at a distance".

\section{The Use of Metaphor}

Lakoff and Johnson (1980:156) argue that while metaphor involves imagination, imagination itself is shaped by the most fundamental values in a culture. The metaphorical structure will, therefore, be coherent with the most fundamental concepts in the culture. In providing coherent structure, metaphors highlight some things and hide others. "Metaphors may create realities for us, especially social realities. A metaphor may thus be a guide for future action. Such actions will, of course, fit the metaphor. This will, in turn, reinforce the power of the metaphor to make experience coherent. In this sense metaphors can be self-fulfilling prophecies".

Lakoff and Johnson (1980:29) identify different types of metaphors, including ontological and orientational metaphors. Ontological metaphors help orient communicators to view things as certain types of entities or substances, and to elaborate from there (e.g. the mind is a machine so the wheels are turning, my head's just not operating today, I'm a little rusty, and I'm running out of steam). Orientational metaphors include spatialization metaphors such as the future is ahead of us, or the past is behind. These metaphors, in their use, reinforce certain metaphorical orientations toward these concepts - for instance, the metaphor of high status 
is another example of an orientational metaphor. Lakoff and Johnson also discuss container metaphors, providing the example of the Western human view of the body as container. "We are physical beings, bounded and set off from the rest of the world by the surface of our skins, and we experience the rest of the world as outside us. ... We impose this orientation on our natural environment as well". They do not critique the basic premise of the conception of bodies being bounded, but this metaphor could be a fruitful site from which to look at discursive constructions of human separation from nature. Lakoff and Johnson discuss how, by hiding other options of conceptualizing, metaphors can influence thinking and constrain lives, leading to exploitation and degradation. In this way, if one sees one's self and others as bounded, one might be less likely to conceptualize connections, interrelatedness, or interdependency with others or with nature. This metaphoric orientation is in line with environmental communication scholars' arguments that metaphors in the West tend to be anthropocentric in character and perpetuate a nature-humanity dualism (Harré et al., 1999:98). The term environment, for instance, is such a metaphor "particularly revealed in the tendency that goes with its use in expressions like 'the environment' to separate human beings from nonhuman nature". Further, the orientational metaphor of "environment" is often used to convey humans as central and nature as peripheral (Goatly, 2002).

A critical approach to communication research looks at both language and practice and "invites attention to the ways in which social inequalities are expressed, reified, and reinforced" (Philipsen, 1992:140). Thus in looking at communication as a process of cultural production, such approaches to language and representation involve not only looking at how communication produces meaning, but also how the meaning or knowledge produced "regulates conduct, makes up or constructs identities and subjectivities, and defines the way certain things are represented, thought about, practiced and studied" (Hall, 1997:6). As this relationship is a dialectical one, it "entails that every instance of language use makes its own small contribution to reproducing and/or transforming society and culture, including power relations. That is the power of discourse; that is why it is worth struggling over" (Fairclough \& Wodak, 1997:275). Beyond specifying threat, such work also has as its goal "to specify emergent practices of resistance, and to discern possibilities for change" (Fairclough, 2000:148).

One example of such communication work is provided by Cohn's (1987) study of what she terms the "technostrategic" language of nuclear think tanks. Cohn entered her research with the explicit purpose of trying to deconstruct how nuclear strategists think, as those in power making decisions that influence the rest of the world. She also entered her work with the reconstructive goal of seeking compelling alternatives. Cohn (1987:715) argued that her experience of learning the "technostrategic" language was a transformative rather than additive process in that the language carried with it a mode of thinking. The militarization of the mind that she argued literally arrived hand-in-hand with the repeated use of technostrategic language made it so strategists did not have to confront the central fact that the purpose of "all weaponry and all strategy is to injure human bodies".

The study of the rationalisation of sociolinguistics processes has resulted in more specific approaches such as Ecolinguistics, with Einar Haugen's work "The Ecology of Language" (Haugen 1972), based on a lecture given in 1970, acknowledged as having laid the foundations for the ecological metaphor as applied to the field of linguistics, where the author defined the title concept as: "the study of interactions between any given language in its environment." Eighteen years later, in 1990, another seminal work was published (Halliday 1990), which opened up a line of research interested in the role that language plays in aggravating or resolving environmental problems and, by extension, other social problems. It is generally agreed that these two lines come together to form the complementary basis for the field of studies known as Ecolinguistics (cf. Fill 1998): the latter is clearly associated with the theoretical framework of Critical Discourse Analysis, whereas the former, which is of interest to us here, could be characterized by using a number of parameters to identify "ecological thinking", e.g.: taking into account external factors (environmental) in the analysis of linguistic systems, rather not just the internal ones; seeing the problems generated by the unilateralism of monocultures; no longer ignoring the fact that natural resources and human capabilities are not unlimited: and omitting the short-term prospects in the analysis and intervention on languages (H. Weinrich 2001:94, cf. Mühlhäusler 2000:308).

Some of the questions raised by this type of approach are far from unimportant: What is the role of linguistic and cultural diversity? On which mechanisms does it depend? Is it possible to optimize it? It should be borne in mind, of course, that approaches exist within the field of Language Planning (especially a certain American tradition), that are not especially interested in the management of diversity and have favoured the study of concepts such as standardization.

For obvious reasons, perspectives such as these do not fit in well with the ecological paradigm. As Mühlhäusler (2000: 310) points, sometimes: "The solution to the adherents of the ecological approach is the problem to most traditional language planners". Linguistic subordination stands as a good example of the 
break in the ecolinguistic equilibrium, involving a social imbalance between two or more human communities whose primary overt expression is the restriction of any or some of the linguistic practices of the subordinate group or groups in favor of the practices of the hegemonic group or groups. Languages in a subordinate position tend to undergo significant structural attrition that gradually renders them ineffective as tools for communication. Also, interference from the dominant language practices may lead to an erosion of subordinate stylistic system that involves a genuine hybridization, leading ultimately to creolization. As far as usage is concerned, subordinate languages are characterized by constant incursions on the part of the dominant language in all areas of use, leading to a narrow and limited functionality, creating a vicious circle that feeds on and exacerbates the subordination. The use of these codes often constitutes a marked usage entailing social stigma for people who use them, thereby encouraging them to abandon the language and making it difficult to attract new users.

The ecological metaphor would ascribe all of these circumstances to the breakdown of the ecolinguistic habitat of a human group. As Bastardas (2000) points out, the maintenance of linguistic diversity has less to do with implementing measures focused on endangered languages, than with creating new contexts adapted to new situations capable of stimulating their continued usage, i.e. the (re) generation of suitable ecolinguistic habitats. Similarly, de Swaan (2001:54) suggests that: A biological species [...] may be saved by safeguarding the environment where it finds its niche. For a language to survive, a considerable number of people must maintain their speech and maybe their ways of life against the inroads of a changing social and linguistic environment - a rather more formidable task.

It is also necessary to bear in mind that we are dealing with social processes where the subjects are beings endowed with reason, which is an important ethical consideration, effectively appealing to the most simplistic applications of the ecological metaphor. As pointed out in an interesting paper (Mufwene 2002:42): Languages die gradually and inconspicuously as a consequence of the communicative practices of the relevant population, in ecologies where the speakers themselves can be considered as victims, as they themselves have adapted to change. We cannot just encourage them to maintain their ancestral languages even if only as home varieties without providing the ecologies that can support our prescriptions.

\section{Exploring the Data}

In this paper, it is assumed that ecolinguistic planning, taken as the rational management of linguistic ecosystems, is a valuable tool for regulating ecolinguistic balance and, additionally, that ecolinguistic policies, necessarily including translation policy, can be a prime tool for this purpose. The following is the example of mantra that can be used as (1) releasing headache, (2) releasing fever

\section{Tawar Sakit Kepala (Releasing headache)}

Bismillahhirahhmanirrahim (In the name of Allah, the Beneficent, the Merciful)

Kayu medang kayu meranti (luarinaceae wood timber wood)

Tumbuh di padang sana menanti (grow in a field there waiting)

Aku menawar sakit kepala (I treat a headache)

Kabul berkat Laillahaillallah, Muhammadurasullulah.(released caused by Allah, Muhammad is as Allah Messenger)

Bismillahhhirahmanirrahim (In the name of Allah, the Beneficent, the Merciful)

Orang tua teranguk anguk (An old man is nodding)

Anak kumbang putus tali (small bumble bee broken off tail))

Di kepala jangan mengetuk (on the head does not knock)

Jangan mendenyut (does not beat)

Kabullah aku mengubati (answered I am treating)

Sakit kepala si ..... (the headache of Mr.............)

Kabul berkat kalimah Laillhaillahlah (answered because the sentence of kalimah Laillhaillahlah, there is no God but Allah)

\section{Tawar Demam (releasing fever)}

Bismillahhirahmanirrahim 
Kurendam -rendam si bunga mawar(I submerged the roses)

Campur dengan si daun pandan (mixed with pandanus leaf)

Seteguk air untuk penawar (a gulp of water as the releaser)

Hilang panas dalam badan (the warm has gone from the body)

Berkat doa Laillahaillahlah, Muhammadurrasulllulah (answered because the sentence of kalimah Laillhaillahlah, Muhammad is a Messanger)

From the mantra above, there are some phrases created from the enfironment (flora and fauna), such as :

1. Kayu medang kayu meranti $=($ luarinaceae wood timber wood $)$

2. di padang (in a field)

3. Anak kumbang (small bumble bee)

4. bunga mawar (the roses)

5. daun pandan (pandanus leaf)

6. Seteguk air (a gulp of water)

\section{Conclusion}

From the two mantras above, it can be found six phrases using words taken from the environment, the surroundings of the society. As the Malay Langkat society believe in Islam, all the mantra are started by the name of God they believe. As it is mentioned previously that the Islamic ways of treatment through mantra or rukyah (incantation), among others, are surah al-Fatihah, al-Kursi verse, muawwidhat verses (surah anNas and surah al-Falaq), etc. As such, spiritual healing by rukyah (incantation) involves the spiritual aspects that require the practitioner to return to fitrah tawhidiyyah, which is to humble oneself with confidence that everything that happens is Allah SWT's will. This treatment is an effort to cleanse the soul with the belief that each illness created by Allah SWT, God Almighty will have a cure. The illness is a form of test from Allah God Almighty, to his followers, who are always patient.

Actually, there are many kinds of mantra that can be found in the Malay Langkat society. The exploration in only two mantra that consist of six phrases about environment as an indication that Malay Langkat mantra or rukyah (incantation) are rich with those kind of words and phrases.

\section{References}

Abram, D. (1997). The Spell of the Sensuous: Perception and Language in a More-than-Human World. New York: Vintage Books.

Adler, J. (1989). Origins of sightseeing. Annals of Tourism Research, 16(7-29).

Andersen, M. S. (2004). Whale Watching and Onboard Marine Environmental Education in the San Juan Islands, Washington: Tourists' Expectations and Evaluations.University of Washington, Seattle.

Basso, K. (1996). Wisdom Sits in Places: Landscape and Language Among the Western Apache. Albuquerque: University of New Mexico Press.

Berger, J. (1980/1991). About Looking. New York: Random House.

Briggs, C. L. (1986). Learning how to ask: A sociolinguistic appraisal of the role of the interview in social science research. Cambridge: Cambridge University Press.

Cameron, D. (1998). Gender, Language, and Discourse: A Review Essay. Signs: Journal of Women in Culture and Society, 23(4), 945-973.

Carbaugh, D. (1996). Naturalizing communication and culture. In J. G. Cantrill \& C. L. Oravec (Eds.), The Symbolic Earth: Discourse and Our Creation of the Environment (pp. 38-57). Lexington: University Press of Kentucky.

Carbaugh, D. (1999). "Just listen": "Listening" and landscape among the Blackfeet. Western Journal of Communication, 63(3), 250-270.

Carbaugh, D. (2001). 'The Mountain' and 'The Project': Dueling depictions of a natural environment. In A. Fill \& P. Muhlhausler (Eds.), The Ecolinguistics Reader: Language, Ecology, and Environment (pp. 124142). London \& New York: Continuum.

Carbaugh, D. (2007). Quoting, "the Environment": Touchstones on Earth. Environmental Communication: A Journal of Culture and Nature, 1(1), 64- 73.332

Carbaugh, D., \& Boromisza-Habashi, D. (2005). Discourse beyond language: Cultural rhetoric, revelatory insight, and nature, Rhetoric Culture 3 Conference. Johannes- 
Denzin \& Y. S. Lincoln (Eds.), Strategies of Qualitative Inquiry (pp. 249-291). Thousand Oaks, London \& Delhi: Sage.

Cox, R. (2007). Nature's "Crisis Disciplines": Does Environmental Communication Have an Ethical Duty? Environmental Communication: A Journal of Culture and Nature, 1(1), 5-20.

Denzin, N. (1997). Interpretive Ethnography: Ethnographic Practices for the $21^{\text {st }}$ Century. Thousands Oaks, CA: Sage.

Fairclough, N. (2000). Guest editorial: Language and neo-liberalism. Discourse \& Society, 11(2), 147-148.

Fairclough, N., \& Wodak, R. (1997). Critical Discourse Analysis. In T. v. Dijk (Ed.), Discourse as Social Interaction (pp. 258-284). London: Sage.

Foucault, M. (1970). The Order of Things. London: Tavistock.

Gamson,W.A.(1988). Political discourse and collective action. In B.Klandermans, H.

Geertz, C. (2000/1973). The Interpretation of Cultures. New York: Basic Books.

Goodman, L. A. (1961). Snowball sampling. Annals of Mathematical Statistics, 32, 148-170.

Hall, S. (Ed.). (1997). Representation: Cultural Representations and Signifying Practices. London: Sage Publications in association with the Open University.

Harré, R., Brockmeier, J., \& Mühlhäuser, P. (1999). Greenspeak: A Study of Environmental Discourse. Thousand Oaks, Calif.: Sage Publications.

Lakoff, G., \& Johnson, M. (1980). Metaphors we live by. Chicago and London: University of Chicago Press. Lange, J. (1990). Refusal to compromise: The case of Earth First! Western Journal of Communication, 54, 473-494.

Montgomery, M. (1994). An Introduction to Language and Society. Routledge: London \& New York.

Morton, A. (2002). Listening to Whales: What the Orcas have Taught Us. New York: Ballantine Books.

Muhlhausler, P., \& Peace, A. (2001). Discourses of ecotourism: The case of Fraser Island, Queensland. Language \& Communication, 21(4), 359-380.

Osborne, R. W. (1999). A Historical Ecology of Salish Sea "Resident" Killer Whales (Orcinus orca): With Implications for Management (pp. 262): University of Victoria Department of Geography.

Philipsen, G. (1992). Speaking Culturally: Explorations in Social Communication. Albany, NY: State University of New York Press.

Philipsen, G. (2002). Cultural communication. In W. B. Gudykunst \& B. Mody (Eds.), Handbook of International and Intercultural Communication (2nd ed., pp. 51-67). Thousand Oaks: Sage.

Sawyer, M. S. (2004). Nonverbal ways of communicating with nature: A cross-case study. In S. L. Senecah (Ed.), The Environmental Communication Yearbook (Vol. 1, pp. 227-249). Mahway, NJ \& London: Lawrence Erlbaum.

Shackley, M. (1996). Wildlife Tourism. London \& Boston: International Thomson Business Press.

Soundwatch. (2007). Soundwatch 2006 Graphs and Commercial Company and Vessel

Port List (pp. saved in diz downloaded studies). Friday Harbor, WA.

Strauss, A., \& Corbin, J. (1998). Basics of Qualitative Research: Grounded Theory, Procedures, and Techniques. Newbury Park, CA: Sage.

Swidler, A. (2001). Talk of Love: How Culture Matters. Chicago: University of Chicago Press.

N. Coupland \& A. Jaworski (Eds.), Sociolinguistics: A Reader and Coursebook (pp. 443-464). New York: St. Martin's Press.

Wilson, A. (1992). The Culture of Nature: North American Landscape from Disney to the Exxon Valdez. Cambridge, MA: Blackwell.

Wilson, E. O. (1984). Biophilia. Cambridge: Harvard University Press. 